\title{
ISLAM DAN HAK ASASI MANUSIA: Penegakan dan Problem HAM di Indonesia
}

\author{
Masykuri Abdillah \\ Fakultas Syariah dan Hukum UIN Syarif Hidayatullah \\ Jl. Ir. Haji Juanda No. 95, Ciputat, Tangerang Selatan, Banten 15412 \\ e-mail: masykuriabdillah@yahoo.com
}

\begin{abstract}
Abstrak: Tulisan ini menjelaskan kompatibilitas Islam dan HAM serta upaya-upaya penegakan dan perlindungan HAM di Indonesia sebagai salah satu negara Muslim. Tulisan ini dengan demikian menolak anggapan sejumlah pengamat tentang ketidaksesuaian atau pertentangan antara Islam dengan HAM, terutama karena sebagian besar negara-negara Muslim kini belum sepenuhnya melindungi dan menegakkan HAM. Sejak awal Islam telah mengakui perlindungan hak asasi manusia (HAM), yang kemudian dirumuskan oleh para ulama dengan konsep maqâshid al-syarî́ah (tujuan syari'ah). Sebagai salah satu negara Muslim, Indonesia di era Reformasi ini telah berkomitmen untuk melakukan perlindungan dan penegakan HAM sejalan dengan penerapan sistem demokrasi secara substantif. Hanya saja, kini masih ada sejumlah masalah atau kendala dalam perlindungan HAM ini, baik yang bersifat substantif, struktural maupun kultural. Pemerintah, DPR serta civil society dan organisasi-organisasi keagamaan telah melakukan upaya-upaya untuk mengatasi persoalan dan kendala itu.
\end{abstract}

\begin{abstract}
Islam and Human Right: Its Application and Problems in Indonesia. This paper explains the compatibility of Islam and human rights as well as efforts to protect human rights in Indonesia as a Muslim country. This paper thus rejects the opinion of a number of observers about the incompatibility or conflict between Islam and human rights just because of the fact that the majority of Muslim countries does not fully protect and enforce human rights. Since the beginning, Islam has recognized the protection of human rights, which were then formulated by the ulama with the concept of maqâsid al-sharî‘ah (objectives of shari'ah). As a Muslim country, Indonesia in the Reform era has committed to the protection and enforcement of human rights in line with the implementation of substantive democracy. Yet there remain a number of problems or obstacles in the protection of human rights caused by several factors, be they substantive, structural or cultural. The government, parliament as well as civil society and religious organizations have conducted efforts to solve the problems and obstacles.
\end{abstract}

Kata Kunci: hak asasi manusia, Islam, tanggung jawab manusia, maqâsid alsharîah, kebebasan 


\section{Pendahuluan}

Pada saat ini hak asasi manusia (HAM) dan demokrasi menjadi isu penting dalam kehidupan berbangsa dan bernegara, bahkan kini perlindungan HAM merupakan prasyarat bagi kerja sama internasional. Hak asasi manusia (HAM) dan demokrasi adalah dua hal yang saling terkait satu sama lain. Demokrasi tidak bisa eksis tanpa adanya hak asasi manusia; dan sebaliknya, hak asasi manusia pada umumnya tidak sepenuhnya terlindungi tanpa adanya demokrasi. Suatu negara yang mengabaikan HAM dapat dipastikan menjadi sasaran kritik oleh dunia internasional, dan ia pun akan terasing dari pergaulan internasional. HAM, yang pada dasarnya bersifat moral dan bukan politis ini menjadi hal yang penting sekali setelah Perang Dunia II dengan lahirnya Universal Declaration of Human Rights (Deklarasi Universal Hak Asasi Manusia atau DUHAM), pada 10 Desember 1948, yang didukung oleh sebagian besar anggota Perserikatan Bangsa-Bangsa (PBB). Hanya saja, pelaksanaan HAM di banyak negara kini masih mengalami banyak hambatan, termasuk di negara-negara Muslim.

Meskipun hampir semua negara Muslim menandatangani piagam tersebut, dalam pelaksanaannya masih banyak dari negara-negara itu yang belum sepenuhnya melaksanakan perlindungan dan penegakan HAM. Ada sejumlah faktor yang melatarbelakangi hal ini, baik karena alasan doktrin keagamaan maupun karena tidak adanya political will dari pemerintah. Sejumlah pengamat bahkan menganggap adanya ketidaksesuaian atau pertentangan antara ajaran Islam dengan HAM. Namun pendapat ini dibantah oleh para ulama dan intelektual Muslim yang mengklaim kompatibilitas ajaran Islam dengan HAM, walaupun mereka juga manyadari adanya hal-hal yang berbeda antara konsep HAM "universal" yang notabene berasal dari peradaban Barat dan konsep HAM menurut Islam.

Sebagai salah satu negara Muslim, Indonesia telah berkomitmen untuk melindungi HAM sejak awal kemerdekaan, sebagaimana ditunjukkan oleh UUD 1945. Hanya saja, variasi tergantung political will dari pemerintah satu periode dengan periode lainnya. Di era reformasi (1998-sekarang) komitmen ini jauh lebih kuat dari pada periode sebelumnya, yang ditunjukkan oleh kebijakan-kebijakan negara yang pro HAM. Meski demikian, kadangkadang masih ada perdebatan mengenai konsep HAM, terutama terkait dengan penyesuaian hak-hak dalam budaya Indonesia sendiri serta adanya sejumlah masalah dan hambatan dalam pelaksanaannya. Tulisan ini akan mendeskripsikan dan menganalisis konsep HAM dalam Islam serta pelaksanaannya di Indonesia beserta problematika dan hambatannya.

\section{Pengertian dan Sejarah HAM}

HAM pada hakikatnya merupakan hak moral dan bukan hak politik. Oleh karenanya, seseorang bisa hidup meski tanpa adanya organisasi politik, seperti yang terjadi pada 
komunitas nomaden dan pemburu, ${ }^{1}$ yang sampai kini masih bisa dijumpai di sejumlah tempat yang terisolasi. Terdapat berbagai definisi tentang HAM ini, baik dalam konteks akademik murni maupun dalam konteks penyesuaian dengan filosofi atau ideologi suatu negara. Salah satu di antaranya adalah definisi yang kemukakan oleh A.J.M. Milne, yakni:

gagasan bahwa ada hak-hak tertentu yang, apakah diakui atau tidak, menjadi milik seluruh umat manusia sepanjang waktu dan di semua tempat. Ini adalah hak-hak yang mereka miliki hanya dalam sifat mereka menjadi manusia, terlepas dari kebangsaan, agama, seks, status sosial, jabatan, kekayaan, atau perbedaan karakteristik etnis, kultur atau sosial lainnya. ${ }^{2}$

Secara historis, gagasan tentang HAM ini berasal dari gagasan tentang hak-hak alamiah (natural rights). Hak-hak alami ini sering dihubungkan dengan konsep hukum alam (natural law), sebagaimana yang dikemukakan oleh John Locke (1632-1705). ${ }^{3}$ Sedangkan hukum alam ini digali dari filosofi tentang kebutuhan dasar (basic needs) manusia. Dalam bentuknya yang lebih kongkret seperti sekarang, HAM ini bermula dicantumkan dalam Declaration of Independence Amerika Serikat pada tahun 1776 : “... that all men are created equal, that they are endowed by their Creator by certain unalienable Rights, that among these are Life, Liberty and pursuit of Happiness...". Hak-hak ini juga dinyatakan dalam Deklarasi Hak-Hak Manusia dan Warganegara (Declaration des Droits de l'Homme at du Citoyen) Prancis pada tahun 1789, dengan slogannya yang populer pada waktu itu, yakni: liberté (kebebasan), egalité (persamaan) dan fraternité (persaudaraan). Baru pada 10 Desember 1948 lahir Universal Declaration of Human Rights (Deklarasi Universal tentang Hak-Hak Asasi Manusia), yang disetujui oleh Majelis Umum PBB dengan hasil perhitungan suara 48 negara menyetujui, 8 negara abastain dan tidak ada satu pun negara yang menolaknya.

Konsep HAM kemudian berkembang, tidak hanya berkaitan dengan hak-hak sipil dan politik secara tradisional, tetapi juga dengan hak-hak ekonomi dan sosial. Memang gagasan HAM pada waktu itu muncul sebagai penolakan campur tangan terhadap kepentingan individu, terutama yang dilakukan oleh negara, yang kini dikenal dengan istilah "negative

${ }^{1}$ A.J.M. Milne, Human Rights and Human Diversity, (Houndmills, Basingstoke, Hamsphire dan London: Macmillan, 1986)h. 154

IIbid., h. 1

${ }^{3}$ Lihat Norman P.Barry, An Introduction to Modern Political Theory, (New York: St. Martin's Press, 1981), h. 182-183. Sebagian ilmuwan menguraikan sejarah HAM, dari segi substansi berawal dari filsafat Yunani yang dikemukakan Socrates (470-399 SM) dan Plato (428-348 SM) dan Aristoteles (348-322 SM), sedangkan dalam bentuk piagam, ketentuan HAM pertama kali dibuat di Inggris dengan munculnya Magna Charta pada 1215 yang berisi pembatasan kekuasaan raja sehingga tidak lagi absolut dan dapat dipertangguingjawabkan di muka hukum. Sebenarnya para nabi juga membawa ajaran-ajaran agama yang di dalamnya terdapat substansi HAM, termasuk Islam yang dibawa Nabi Muhmmad. Bahkan jika dibandingkan, Piagam Madinah yang dibuat pada masa-masa awal Nabi di Madinah jauh lebih dahulu dari pada Magna Charta. 
rights". Namun dalam perkembangannya, ia juga diinterpretasikan sebagai pemberi legitimasi kepada pemerintah untuk mencukupi kebutuhan-kebutuhan rakyat, yang kini dikenal dengan istilah "positive rights" atau hak-hak ekonomi dan sosial. PBB menyutuji pengembangan konsep HAM ini, dengan meratifikasi tiga persetujuan, yakni International Covenant on Economic, Social and Cultural Rights; International Covenant in Civil and Political Rights; dan Optional Protocol to the International Covenant on Civil and Political Rights pada tahun $1966 .{ }^{4}$

Namun demikian, dalam praktiknya konsep HAM tersebut tetap mengandung perbedaan, terutama antara negara-negara liberal dengan negara-negara sosialis dan negara-negara Muslim. Negara liberal memberikan prioritas kepada hak-hak sipil dan politik berdasarkan prinsip "individualisme", sedangkan negara sosialis atau komunis memberikan prioritas kepada hak-hak ekonomi dan sosial berdasarkan prinsip "kolektivisme". Konsep universal HAM ini kemudian juga ditafsirkan lagi oleh beberapa negara berkembang (dulu sering disebut Dunia Ketiga), dengan maksud untuk menyesuaikan konsep HAM sesuai dengan kondisi dan budaya lokal atau regional. Banyak elite politik serta para intelektual di Dunia Ketiga, termasuk di Indonesia, tidak menerima konsep individualisme maupun sosialisme bagi masyarakat mereka. Mereka merumuskan, mendefinisikan dan mengadaptasikan budaya-budaya tradisional dan doktrin-doktrin filosofis untuk menggabungkan dan menjustifikasi ide-ide modern tentang hak-hak ke dalam tradisi mereka. Usaha semacam itu cenderung untuk mengambil bentuk komunalisme dengan menyusun dan mengubah sistem-sistem nilai komunal secara tradisional yang mengartikulasikan hubungan timbal balik antarindividu ke tingkat nasional negara modern. ${ }^{5}$ Hal yang sama juga dilakukan oleh negara-negara Muslim, yang umumnya tetap menjadikan agama sebagai unsur penting dalam kehidupan masyarakat dan negara, yang berarti tidak ada pemisahan sepenuhnya antara agama dan negara.

Oleh karena itu, bisa dipahami jika muncul beberapa deklarasi hak-hak asasi manusia yang berifat regional, seperti Convention for the Protection of Human Rights and Fundamental Freedoms pada tahun 1950 yang didukung oleh negara-negara Eropa, dan African Charter

${ }^{4}$ Sebagian pengamat menganggap bahwa lahirnya Universal Declaration of Human Rights pada tahun 1948 yang menekankan pada hak-hak sipil dan politik merupakan konsep HAM generasi pertama, sementara pengembangan konsep hak-hak ekonomi dan sosial sebagai perkembangan konsep HAM generasi kedua. Sedangkan perkembangan konsep HAM generasi ketiga terkait dengan hak-hak perdamaian dan pembangunan, yang dikenal dengan solidary rights tetapi deklarasinya hanya didukung oleh negara-negara Dunia Ketiga (negara-negara berekembang).

${ }^{5}$ Lihat Adamantia Polis, "Human Right", dalam Mary Hawkesworth dan Maurice Kogan (eds.), Encyclopedia of Goverment and Politics, Vol. 2, (London dan New York: Routledge, 1992), hlm. 1332-1335. Beberapa analis menyatakan bahwa hak-hak asasi manusia adalah universal, karena itu membantah klaim bahwa hak asasi manusia relatif secara kultural. Komunalisme didefinisikan sebagai "teori pemerintahan yang mendukung perluasaan otonomi lokal untuk setiap komunitas yang dapat dijelaskan secara lokal. Lihat J.A. Simpson dan E.S.C. Weiner, op. cit., hlm. 576. 
of Human and People's Rights pada tahun 1981. Dalam hal ini, Asia adalah satu-satunya wilayah yang belum memiliki piagam HAM yang bersifat regional. Baru pada tahun 1993 pemerintah negara-negara di Asia menandatangani The Bangkok Declaration yang menegaskan komitmen mereka kepada prinsip-prinsip yang terdapat dalam piagam PBB dan Universal Declaration of Human Rights. Deklarasi ini dipersiapkan untuk Konferensi Dunia tentang hak-hak asasi manusia pada bulan Juni 1993 di Wina. ${ }^{6}$ Pemerintah-pemerintah di negara-negara berkembang yang membatasi HAM pada umunya beralasan, bahwa pelaksanaan HAM yang dalam hal-hal tertentu dibatasi itu dimaksudkan untuk mewujudkan stabilitas nasional sebagai pra-syarat bagi pembangunan. Pada pertengahan tahun 1980an negara Dunia Ketiga mengeluarkan deklarasi hak untuk perdamaian dan pembangunan, yakni Declaration on the Rights of Peoples to Peace (1984) dan Declaration on the Rights to Development (1986). Di samping itu, perbedaan juga dimaksudkan untuk meyesuaikan konsep HAM dengan karakteristik sosial budaya suatu masyarakat di negara-negara berkembang, termasuk di dunia Islam.

Pada 18 November 2012 lalu negara-negara anggota ASEAN menandatangi ASEAN Human Rights Declaration di Pnom Phen, Kamboja. Kedua deklarasi di atas diakomodasi dalam deklarasi ASEAN ini, yakni right to development (hak untuk pembangunan, pasal 35,36 dan 37) dan right to peace (hak untuk perdamaian, pasal 38). Deklarasi yang sebenarnya mengacu kepada DUHAM ini menegaskan tentang pelaksanaannya untuk mempertimbangkan konteks regional dan nasional masing-masing negara dengan melihat latarbelakang perbedaan latar politik, ekonomi, hukum, sosial, budaya, sejarah dan agama (pasal 7). Disamping itu, ekspresi kebebasan juga perlu memperhatikan keamanan nasional, ketertiban dan kesejahteraan umum serta kesehatan dan moraltas publik (pasal 8).

Memang pemerintah dan masyarakat di negara-negara berkembang pada umumnya tidak mau mengidentifikasikan masyarakatnya dengan kedua bentuk di atas, melainkan dengan karakteristik lain yang diangkat dari budaya setempat dan doktrin filosofinya, seperti "komunalisme". ${ }^{7}$ Hanya saja, di balik alasan penyesuaian karaktersitik budaya lokal ini kadang-kadang upaya penyesuaian HAM dimaksudkan untuk menjustifikasi sistem politik otoriter yang diterapkan oleh suatu pemerintah tertentu, atau bahkan untuk melanggengkan kekuasaannya, seperti yang terjadi pada masa pemerintahan Orde Baru (1966-1998). Misalnya dengan alasan tidak sesuai dengan budaya masyarakatnya, suatu pemerintah membatasi kebebasan pers, kebebasan warganya dalam mengekspresikan pendapatnya atau pilihannya, dan sebagainya. Suatu hal yang dapat mendekatkan antara HAM Barat dengan HAM yang dipahami oleh umumnya negara-negara berkembang adalah munculnya wacana tentang kewajiban atau tanggung jawab manusia (human responsibility).

${ }^{6}$ Lihat Miriam Budiardjo, "Hak-hak Asasi Manusia dalam Dimensi Global" dalam Jurnal Ilmu Politik, Vol. 10, 1990; dan SOA-Informationen, Vol. 1, 1988, hlm. 4-5.

${ }^{7}$ Lihat Adamantia Pollis, "Human Rights", dalam Mary Hawkesworth dan Maurice Kogan (ed.), Encyclopedia of Government and Politics, Vol. 2, (London dan New York : Routledge, 1992), h. 1332-1335. 


\section{HAM dalam Islam}

Berbeda dengan istilah dan sistem demokrasi yang sampai kini masih diperdebatkan di antara ulama serta intelektual dan aktivis Muslim, hampir semua mereka setuju dengan istilah hak-hak asasi manusia (HAM) ini, meskipun konsep yang mereka kemukakan tidak sepenuhnya sama dengan konsep liberal. Penerimaan ini disebabkan karena essensi dari HAM ini sudah diakui oleh Islam sejak masa permulaan sejarahnya. Di dalam Al-Quran dan Hadits disebutkan bahwa manusia dijadikan sebagai khalifah Allah di atas bumi, yang dikaruniai kemuliaan dan martabat yang harus dihormati dan dilindungi. Di antara ayat Al-Quran yang menunjukkan hal ini adalah Q.S. Al-Isra': 70, yakni “Dan sesungguhnya telah Kami muliakan anak-anak Adam ...". Hal ini mengandung pengertian bahwa manusia secara fitrah (natural) memiliki kemulian (karamah) dan oleh karenanya kemulian ini harus dilindungi. ${ }^{8}$ Di antara Hadits yang menunjukkan persamaan umat manusia dan penghormatan martabat mereka adalah "Manusia pada dasarnya adalah sama dan sederajat bagaikan gigi-gigi sisir, tidak ada keistimewaan bagi orang Arab atas orang non-Arab kecuali karena ketaqwaannya". ${ }^{9}$

Dalam persepektif Islam, konsep HAM itu dijelaskan melalui konsep maqâshid alsyarî'ah (tujuan syari'ah), yang sudah dirumuskan oleh para ulama masa lalu. Tujuan syari'ah (maqâshid al-syarî’ah) ini adalah untuk mewujudkan kemaslahatan (mashlahah) umat manusia dengan cara melindungi dan mewujudkan dan melindungi hal-hal yang menjadi keniscayaan (dharûriyyât) mereka, serta memenuhi hal-hal yang menjadi kebutuhan (hâjiyyât) dan hiasan (tahsîniyyât) mereka". ${ }^{10}$

Teori maqâshid al-syarî'ah tersebut mencakup perlindungan terhadap lima hal (aldharûriyyât al-khamsah), yakni: (1) perlindungan terhadap agama (hifzh al-din), yang mengandung pengertian juga hak beragama, (2) perlindungan terhadap jiwa (hifzh alnafs), yang mengandung pengertian juga hak untuk hidup dan memperoleh keamanan, (3) perlindungan terhadap akal (hifzh al-'aql), yang mengandung pengertian juga hak

${ }^{8}$ Menurut Hasbi Ash-Shiddieqy, ada tiga karamah (kemuliaan) yang dianugerahkan Tuhan kepada manusia terlepas dari latar belakang etnik, agama dan politik mereka, yakni: (1) karamah fardiyyah (kemuliaan individual) yang berartti bahwa Islam melindungi aspek-aspek kehidupan manusia baik aspek spiritual maupun meterial., (2) karamah ijtima'iyyah (kemuliaan kolektif) yang berarti bahwa Islam menjamin sepenuhnya persamaan di antara individu-individu, dan (3) karamah siyasiyyah (kemuliaan secara politik) yang berarti bahwa Islam memberi hak politik pada individu-individu untuk memilih atau dipilih pada posisi-posisi politik, karena mereka adalah wakil Allah. Dikutip dalam Ahmad Syafii Maarif, Islam dan Masalah Kenegaraan (Jakarta: LP3ES, 1

${ }^{9}$ Hadits tersebut dilanjutkan dengan ucapan Nabi: "Wahai manusia, sungguh darahmu, hartamu dan kehormatan (martabat) mu adalah suci, terhormat". Hadits lain tentang HAM ini adalah Umar bin Khattab kepada Amr ibn Ash, gubemur Mesir yang memperlakukan seorang warganya dengan kasar, "Mengapa kamu memperlakukan rakyatmu seperti budak, padahal mereka dilahirkan oleh ibunya sebagai manusia yang merdeka".

10‘Abd al-Wahhâb Khallâf, 'Ilm Ushûl Fiqh, (Kuwait : Dâr al-Qalam, cet. 12, 1978), h. 199. 
untuk memperoleh pendidikan, (4) perlindungan terhadap harta (hafizh al-mal), yang mengandung pengertian juga hak untuk memiliki harta, bekerja dan hidup layak, (5) perlindungan terhadap keturunan (hifzh al-nasl), yang mengandung pengertian juga hak untuk melakukan pernikahan dan mendapatkan keturunan. Sebagian ulama menyebutkan perlindungan terhadap kehormatan (hifzh al-irdh) sebagai ganti hifzh al-nasl, yang mengandung pengertian hak untuk memiliki harga diri dan menjaga kehormatan dirinya.

Eksistensi kemuliaan manusia (karamah insâniyyah) akan terwujud dengan perlindungan terhadap lima hal tersebut. Tujuan syari'ah (maqâshid al-syari'ah) tersebut diperkuat dengan prinsip-prinsip hukum Islam yang meliputi 'adl (keadilan), rahmah (kasih sayang), dan hikmah (kebijaksanaan) baik dalam hubungan dengan Allah, dengan sesama manusia maupun dengan alam. ${ }^{11}$ Para ulama dan intelektual Muslim kemudian mengembangkan konsep tersebut dengan berbagai hak sebagaimana yang terdapat dalam Deklarasi HAM tersebut, terutama: (1) hak untuk hidup, (2) hak kebebasan beragama, (3) hak kebebasan berpikir dan berbicara, (4) hak memperoleh pendidikan, (5) hak untuk bekerja dan memiliki harta kekayaan, (5) hak untuk bekerja, dan (6) hak untuk memilih tempat tinggal sendiri.

Hanya saja, beberapa pengamat, Islamolog dan bahkan banyak intelektual Muslim sendiri melihat adanya perbedaan atau pertentangan antara Islam dan prinsip-prinsip HAM dalam hal-hal tertentu. Sebagian ulama dan intelektual Muslim menjelaskan HAM dalam Islam dengan cara apologetik, dengan menyatakan bahwa Islam merupakan sistem yang paling sempurna, sehingga jika ada perbedaan atau pertentangan antara HAM dan ajaran Islam, maka HAM itu harus ditolak. Memang ada di antara intelektual Muslim yang menganjurkan perlunya reinterpretasi secara bebas terhadap teks-teks Al-Qur'an dan Hadits serta hasil ijtihad ulama klasik yang tidak sesuai dengan prinsip-prinsip HAM, walaupun teks-teks itu bersifat absolut ( $q a$ th’i). Namun pendapat yang sangat bebas (liberal) ini ditolak oleh para ulama dan sebagian besar intelektual Muslim.

Berbeda dengan kedua pendapat di atas, cukup banyak intelektual Muslim mencoba melihat persoalan HAM dalam Islam secara lebih kritis, walaupun tetap konsisten menggunakan metodologi standar yang telah disepakati oleh para ulama. Mereka pun berusaha untuk melakukan harmonisasi antara Islam dan HAM dengan menjelaskan persoalan tersebut serasional mungkin dan melakukan reinterpretasi terhadap hal-hal yang secara lahiriah bertentangan dengan melakukan reinterpretasi dalil-dalil itu secara filosofis dan sosiologis. Di antara hal-hal yang dinilai tidak kompatibel antara ajaran Islam dan HAM adalah terkait dengan batas-batas kebebasan dan ketidaksamaan antara Muslim dan non-Muslim serta antara pria dan wanita. Dalam pasal 1 DUHAM disebutkan: "Semua orang dilahirkan merdeka dan mempunyai martabat dan hak yang sama", tetapi di dalam

${ }^{11}$ Lihat Ibn Qayyim al-Jauziyyah, I'lâm al-Muwaqqiîn, (Beirut: Dar al-Kutub al-"ilmiyyah, 1991), h. 11-12. 
Islam terdapat batasan-batasan yang lebih besar dalam mengekspresikan kebebasan ini. Sebagai sebuah agama yang berarti juga panduan yang mengikat, Islam tentu saja memberikan batasan-batasan yang lebih besar terhadap kebebasan dari pada HAM universal. ${ }^{12}$ Di samping itu, di dalam Islam terdapat ketidaksamaan tertentu antara Muslim dengan non-Muslim dan antara pria dan wanita, ${ }^{13}$ suatu kondisi yang dinilai tidak sesuai dengan salah satu prinsip HAM yang menyatakan persamaan manusia. Ketidaksesuaian antara doktrin Islam dan HAM "universal" ini hanya terdapat dalam beberapa hal saja, yakni terkait dengan batas-batas kebebasan serta ketidaksamaan antara Muslim dan Muslim dan antara pria dan wanita.

Kebebasan mengandung pengertian, bahwa "seorang dalam batas-batas tertentu dapat melakukan atau meninggalkan apa yang ia inginkan. Batas-batas ini mungkin bersifat biologis atau hukum positif". ${ }^{14}$ Sedangkan kebebasan beragama diartikan sebagai sebuah gagasan yang mempromosikan kebebasan individu atau kolektif untuk mengekspresikan agama mereka dan kepercayaan dalam pengajaran dan praktek, baik dalam kehidupan pribadi maupun publik. Kebebasan ini juga umumnya mengakui kebebasan untuk mengubah agama atau tidak mengikuti agama apapun. Dalam hal kebebasan beragama yang merupakan kebebasan yang paling fundamental, Q.S. al-Baqarah: 256 secara jelas menyebutkan adanya kebebasan ini, yakni "Tidak ada paksaan dalam agama". Memang fiqh klasik mengenakan hukuman mati terhadap orang yang keluar dari Islam (murtad), suatu hal yang tidak boleh terjadi dalam HAM. Di samping itu, Islam menyuruh umatnya untuk menolak pihak-pihak yang melakukan penyimpangan secara mendasar dari ajaran-ajaran Islam, suatu hal yang juga tidak dibenarkan menurut HAM "universal".

Upaya-upaya harmonisasi ajaran Islam dengan HAM dalam persoalan riddah (keluar dari Islam) dilakukan dengan melakukan reinterpretasi dalil-dalil yang menunjukkan adanya hukuman mati terhadap pelakunya, yakni hadits "Barangsiapa merubah agamanya, maka bunuhlah". Meski Hadits ini merupakan hadist ahad yang shahih, tetapi sanad hadits

\footnotetext{
${ }^{12}$ Pembatasan tersebut sesuai dengan Hadits: "Sesungguhnya Allah telah mewajibkan beberapa kewajiban, maka janganlah kamu sia-siakan kewajiban itu; dan Allah telah memberikan beberapa larangan, maka jangan kamu langgar larangan itu; dan Allah telah mengharamkan sesuatu, maka jangan kamu pertengkarkan dia; dan Allah telah mendiamkan beberapa hal sebagai tanda kasihnya kepada kamu, Dia tidak lupa, maka jangan kamu perbincangkan dia." (H.R. Al-Daraquthni).

${ }^{13}$ Lihat, antara lain, John L. Esposito dan James P. Piscatori, "Democratization and Islam", dalam Middle East Journal, Vol. 45, No. 3, 1991, h. 428; dan Abdullah Ahmad An-Naim, Nahw Tathwîr al-Tasyrî‘ al-Islâmî, (Kairo: Sina li Al-Nasyr, 1994), h. 222-224. Di samping tentang persoalan kedudukan non-Muslim dan wanita, An-Naim juga menyebutkan persoalan perbudakan yang yang secara literal dibenarkan oleh Syari'ah. Lihat ibid., h. 218-222. Munawir Sjadzali juga menyebutkan ketiga persoalan ini. Lihat, Munawir Sjadzali, "Reaktualisasi Ajaran Islam", dalam Iqbal Abdurrauf Saimima (ed.), Polemik Reaktualisasi Ajaran Islam, (Jakarta : Pustaka Panjimas, 1988), h. 4 dan 9; dan Islam dan Tata Negara: Ajaran, Sejarah dan Pemikiran, (Jakarta: UI-Press, 1990), h. 178.

${ }^{14}$ Werner Becker, Die Fretheit, die wer weinem, (Munchen-Zurich: R. Riper \& Co., Verlag, edisi ke-2, 1982), h. 111
} 
'amalî yang menyatakan bahwa Nabi melaksanakan hukum mati terhadap orang yang murtad adalah lemah (dha'̂ff), ${ }^{15}$ sementara ayat-ayat al-Quran yang mengungkapkan persoalan riddah ini tak satu pun memberikan hukuman di dunia terhadap orang murtad. ${ }^{16}$ Dengan demikian, dasar hukum tentang hukuman riddah ini tidak qath'i (menunjukkan arti pasti atau absolut), dan oleh karenanya, pada saat ini perlu ditafsirkan kembali, dengan memberikan kebebasan kepada seseorang untuk memeluk Islam atau meninggalkannya tanpa hukuman. Menurut Mahmud Syaltut, hukuman hudûd (mati) tidak bisa ditetapkan dengan hadits ahad, sedangkan kekafiran itu sendiri juga tidak menjadi penyebab diperbolehkan memerangi non-Muslim, melainkan sikap mereka memerangi orang-orang Muslim yang dapat memperbolehkan Muslim memerangi mereka. ${ }^{17}$ Para ulama klasik memberikan hukuman mati kepada seorang yang murtad sebenarnya tidak terlepas dari realitas sosiologis dan politis pada waktu itu, dimana hubungan antarkelompok masyarakat didasarkan pada hubungan konflik. Ketika seseorang keluar dari suatu komunitas (agama) dan bergabung dengan komunitas (agama) lain, maka ia akan menjadi musuh bagi komunitas awalnya. Hal ini tidak terjadi pada saat ini, dimana hubungan antarkelompok didasarkan pada perdamaian yang dikontrol oleh masing-masing negara dan hukum internasional. ${ }^{18}$

Mengenai ketidaksamaan kedudukan non-Muslim dengan Muslim tercermin dalam ilmu fiqh klasik yang membagi warga negara menjadi muslim dan non-Muslim. Kemudian non-Muslim ini dibedakan menjadi: dzimmî (non-Muslim yang mendapatkan perlindungan), harbî (non-Muslim yang menjadi warga wilayah non-Muslim) dan musta'min (harbî yang mendapatkan perlindungan sementara di wilayah Muslim). Dzimmî dan musta'min ini berkewajiban membayar pajak, dengan imbangan mereka berhak memilki kebebasan beragama serta keamanan jiwa dan hartanya. Tetapi mereka tidak memiliki hak sepenuhnya seperti yang dimiliki oleh Muslim, tertama hak untuk ikut serta dalam pertahanan negara dan agama, serta hak memegang jabatan tertentu dalam organisasi negara, yakni sebagai kepala negara (imâm) dan sebagai menteri yang memiliki wewenang penuh (wazîr al-tafwîdh). ${ }^{19}$

${ }^{15}$ Al-Sayyid Sâbiq, Fiqh Al-Sunnah, Jilid II, (Beirut : Dâr al-Kitâb al-Arabî, 1987), h. 408-409. Namun seperti sebagian besar ulama pada masa lalu, dia juga setuju dengan hukum mati ini.

${ }^{16}$ Hukuman bagi orang murtad akan diberikan nanti di hari kiamat, sebagaimana dikatakan dalam Al-Qur'an (2: 217): "Barang siapa di antara kamu murtad dari agamanya, lalu dia mati dalam kekafiran, maka mereka itulah yang sia-sia amalnya di dunia dan di akhirat. Dan mereka itulah penghuni nereka, mereka kekal di dalamnya"; dan Al-Qur'an (4: 137): "Sesungguhnya orang-orang yang beriman lalu kafir, kemudian beriman (pula) kemudian kafir lagi, dan kemudian sertambah kekafirannya, maka sekali-kali Allah tidak akan memberi ampunan kepada mereka, dan tidak (pula) menunjukkan mereka kepada jalan yang lurus."

${ }^{17}$ Mahmud Syaltut, Al-Islâm 'Aqîdah wa Syarî'ah, (Kairo: Dar al-Qalam, 1966), h. 289. Di antara intelektual yang tidak setuju dengan hukuman mati dan menjelaskannya secara lebih detail adalah Fazlurrahman. Lihat artikelnya, "Non-Muslim Minority on an Islamic State", dalm Journal Institute of Muslim Minority Affairs, Vol. 7 No. 1, 1986, p. 16.

${ }^{18}$ Mamud Syaltut, op.cit, h. 461.

${ }^{19}$ Lihat, misalnya, Abû Ya'lâ al-Farra', Al-Ahkâm al-Sulthâniyyah, (Mesir : Mustafâ al-Bâbî al-Halabî), h. 16. 
Pada saat ini para ulama tidak lagi mengklasifikasikan warganegara yang demikian ini, karena kondisi sosial politik sudah berbeda dengan kondisi pada saat itu. Warga negara merupakan satu kesatuan bangsa yang telah melakukan kesepakatan atau perjanjian (mu'âhadah) untuk membangun sebuah negara yang terdiri atas berbagai kelompok masyarakat.

Sedangkan tentang kedudukan wanita, dalam al-Qur'an terdapat tiga ketentuan yang secara lahirnya terlihat ketidaksamaan kedudukan antara wanita denga pria, yakni tentang hukum kewarisan (al-Nisa': 11) dan kesaksian (al-Baqarah: 282) yang menunjukkan perbandingan antara laki-laki dan perempuan 2:1, dan tentang poligami (al-Nisa: 3) yang menunjukkan perbandingan 4:1. Pada umumnya ulama dan intelektual Muslim tetap mempertahankan ketentuan-ketentuan tersebut karena dalil-dalinya bersifat absolut (qath'i). Memang tidak mudah menjelaskan tentang perbedaan ini secara rasional dan dalam persepktif HAM. Di antara mereka kemudian menyadari bahwa ketidaksamaan itu mengandung hikmah yang belum diketahui oleh manusia. ${ }^{20}$ Dalam konteks ini, yang bisa dilakakukan dalam konteks kesataraan kedudukan antara wanita dan pria ini adalah upaya-upaya menghilangkan ketidaksamaan atau diskriminasi yang didasarkan pada dalil-dalil relatif (zhannî) dan yang disebabkan oleh faktor-faktor sosiologis, seperti kesempatan memperoleh pendidikan dan pekerjaan serta kesempatan memegang jabatan dalam kehidupan masyarakat dan negara. ${ }^{21}$

Letak persoalan dasarnya sebenarnya perbedaan filosofi dan budaya antara negaranegara Barat yang sekular yang dijadikan sebagai acuan utama dalam pelaksanaan HAM dengan negara-negara Muslim yang tidak bisa melepaskan aspek agama (syari'ah). Untuk menunjukkan, bahwa Islam juga sangat menghargai HAM sekaligus menyusun suatu rumusan yang sejalan dengan Syari'ah, pada tahun 1990 negara-negara Muslim yang tergabung dalam Organisasi Konferensi Islam mengeluarkan Cairo Declartion of Human Rights in Islam. Sehubungan dengan hal ini, perlu dikembangkan konsep tentang universalisme dan pertikularisme HAM, sehingga pelaksaan HAM itu dapat disesuaikan dengan filosofi dan budaya masingmasing bangsa dan negara. Namun penyesuain atau praktik partikularisme HAM ini harus terhindar dari manipulasi atau kepentingan politik penguasa.

Deklarasi itu baru dapat disetujui oleh semua anggoatanya setalah 13 tahun terjadi perdebatan di antara mereka. Deklarasi tersebut terdiri dari 25 pasal, yang mencakup hak-hak individu, sosial, ekonomi dan politik. Semua hak dan kebebasan yang terdapat dalam deklarasi ini tunduk kepada Syari'ah (pasal 25). Hak-hak sipil dan politik terdiri dari, misalnya, hak memperoleh persamaan martabat manusia serta kewajiban dan tanggung

${ }^{20}$ Memang ada beberapa intelektual Muslim yang mengajukan reinterpretasi ayat-ayat tersebut, yang berarti merubah ketentuan tersebut, namun sejauh ini reinterpretasi mereka itu tidak dapat diterima oleh mayoritas ulama dan umat Islam.

${ }^{21} \mathrm{Di}$ antara ketidaksetaraan antara wanita dan pria dalam fikih-fikih klasik adalah larangan terhadap wanita menjadi kepala negara atau kepala pemerintahan, yang didasarkan pada sebuah hadits: "Suatu masyarakat/bangsa tidak akan bahagia apabila dimpimpin oleh seorang wanita". 
jawab kemanusiaan (pasal 1), hak memperoleh persamaan dalam hukum (pasal 19), hak untuk hidup yang merupakan pemberian Tuhan (pasal 2), dan hak untuk mengemukakan pendapat secara bebas sejauh tidak bertentangan dengan prinsip-prinsip Syari'ah (pasal 22). Hak-hak sosial dan ekonomi terdiri dari, misalnya, hak untuk memperoleh pendidikan (pasal 9), hak untuk bekerja (pasal 13), hak untuk memiliki harta (pasal 15), hak untuk memperoleh kehidupan yang layak (pasal 17), hak untuk hidup dalam keamanan untuk diri seseorang, agamanya, tanggungannya, kehormatannya dan hartanya (pasal 18), dsb. Dalam bidang sosial dan ekonomi, deklarasi ini memuat banyak hak-hak yang fundamental, tetapi dalam bidang politik, ia belum mencakup semua hak yang fundamental, seperti hak untuk berserikat. Hal ini barang kali disebabkan, karena banyak negera Muslim yang menandatangani deklarasi ini belum sepenuhnya memberikan hak-hak politik kepada warganya.

Dengan demikian, di samping karena perbedaan filosofis antara Barat dengan Islam, persoalan itu juga disebabkan karena faktor kemauan politik (political will) dari suatu pemerintah di negara Muslim. Banyak negara Muslim telah berupaya melakukan penyesuaian praktik HAM yang dimaksudkan agar sesuai dengan budaya masyarakatnya. Namun dalam kenyataannya, penyesuaian ini lebih banyak dimaksudkan untuk menjustifikasi sistem politik yang dipromosikan oleh pemerintah negara itu, bukan untuk mendekatkan konsep HAM ini kepada doktrin Islam. Bahkan ada juga alasan untuk menyesuaikan dengan konsep Islam, tetapi di balik itu, penyesuaian itu dimaksudkan untuk menjustifikasi sistem politiknya dan melanggengkan kekuasaannya. ${ }^{22}$ Di sisi lain, pelaksanaan HAM di negaranegara Muslim yang belum sesuai dengan Islam serta adanya standar ganda (double standard) negara-negara Barat dalam beberapa kasus pelaksanaan HAM, mengundang munculnya gerakan fundamentalisme di beberapa negara Muslim. Gerakan ini bahkan sering bersifat eksklusif dan menolak semua peradaban Barat, termasuk sistem demokrasi dan HAM, sehingga mengesankan adanya konflik antara Islam dan Barat. Kondisi ini diperburuk dengan klaim sebagian besar masyarakat Barat, bahwa peradaban merekalah yang paling unggul; dan oleh karenanya harus disebarluaskan ke seluruh dunia, tanpa menyadari bahwa masyarakat lainnya sebenarnya sudah memiliki nilai-nilai sosial dan peradabannya sendiri yang tak kalah unggulnya.

\section{Kebijakan terhadap HAM}

Sebagai salah satu negara muslim, Indonesia telah menunjukkan komitmennya untuk menghormati dan melindungi hak asasi manusia (HAM) sejak awal kemerdekaan, seperti yang ditunjukkan oleh UUD 1945 yang secara eksplisit menyebutkannya. Hanya, saja

${ }^{22}$ Lihat Ahuddin al-Hilal, dkk., Al-Dimuqratiyya wa Haquq al-Insan fi al-Watan al-Arabi, (Beirut, Lebanon: Markaz Dirasah al-Wahdah al-'Arabiyyah, 1986). Walaupun buku ini ditulis tiga puluh tahun lalu, tetapi kondisi tentang hak-hak asasi manusia tidak ada perubahan yang berarti, kecuali di Tunisia, yang telah berhasil melakukan revolusi pada 2011 dan kini sedang menjalani transisi demokrasi yang sudah menunjukkan keberhasilannya. 
pada masa lalu terdapat perbedaan penafsiran pemerintah terhadap HAM, yang terkait dengan kecenderungan politiknya. Pemerintahan Orde Baru memahami HAM dalam konteks masyarakat Indonesia yang "integralistik", yang tidak terlepas dari upaya-upaya untuk membatasi hak-hak sipil dan politik warga negara. Karakterisasi ini pertama kali diungkapkan Soepomo pada sidang BPUPKI tahun 1945 untuk menyatakan bahwa masyarakat Indonesia itu merupakan kesatuan hidup, yang antara lain termanifestasi dalam bentuk tiadanya dualisme antara negara dan masyarakat (Staat und staatsfreie Gesellschaft) serta antara hak-hak asasi dan kebebasan individual (Grund-und Freiheitsrechte) berhadapan dengan negara. ${ }^{23}$ Namun gagasan Soepomo ini ditolak sidang dengan diterimanya usul Mohammad Hatta memasukkan hak-hak dan kewajiban warga negara dalam UUD 1945. Dengan lengsernya Soeharto dari jabatannya sebagai presiden, maka konsep masyarakat integralistik ini pun ikut menghilang.

Munculnya "era reformasi" menyusul jatuhnya pemerintahan otoriter Soeharto pada tahun 1998 ditandai sebagai titik awal dari transisi menuju demokrasi yang substantif di Indonesia, yang juga berarti komitmen yang lebih besar untuk perlindungan HAM. Komitmen itu ditunjukkan dengan terbitnya Ketetapan MPR No. XVII/MPR/1998 Tentang Hak Asasi Manusia, yang kemudian diikuti dengan legislasi UU No. 09/1998 tentang Kemerdekaan Menyampaikan Pendapat Di Muka Umum. Kebijakan ini kemudian ditindaklanjuti dengan legislasi UU No. 39/1999 tentang HAM, diikuti oleh UU No. 26/2000 tentang Pengadilan HAM. Pengertian HAM yang terdapat dalam pasal 1 UU No. 39/1999 adalah "seperangkat hak yang melekat pada hakikat dan keberadaan manusia sebagai makhlukTuhan Yang Maha Esa dan merupakan anugerah-Nya yang wajib dihormati, dijunjung tinggi dan dilindungi oleh negara, hukum, Pemerintah, dan setiap orang demi kehormatan serta perlindungan harkat dan martabat manusia".

Di samping itu, beberapa peraturan telah dicabut atau diubah, seperti UU No. 11/ PnPs/1963 tentang Pemberantasan Kegiatan Subversi, karena UU bertentangan dengan hak asasi manusia dan prinsip negara yang berdasarkan atas hukum serta menimbulkan ketidakpastian hukum. UU ini dicabut dengan UU No. 26/1999 tentang Pencabutan UU No. 11/PnPs1963 tentang Pemberantasan Kegiatan Subversi. Yang lebih penting lagi adalah amandemen kedua UUD 1945 pada tahun 2000, yang menyebutkan HAM secara rinci. Penguatan instrument HAM ini dilanjutkan dengan ratifikasi sejumlah perjanjian internasional tentang HAM. Pada tahun 2005, Dewan Perwakilan Rakyat (DPR) meratifikasi International Covenant on Economic, Social and Cultural Rights (ICESCR) dengan UU No. 11 tahun 2005, dan International Covenant on Civil and Political Rights (ICCPR) dengan UU No.12 tahun 2005. Ratifikasi ini dianggap sebagai sebuah peristiwa bersejarah, karena di era Orde Baru banyak intelektual dan aktivis hak asasi manusia menyarankan pemerintah

${ }^{23}$ Lihat Muhammad Yamin (ed.), Naskah Persiapan Undang-Undang Dasar 1945, Jilid I, (Jakarta: Prapanca, 1959), h. 112-113. 
dan DPR untuk meratifikasi kedua covenan (perjanjian) tersebut, tetapi pemerintah selalu menolak saran itu.

Dengan legislasi HAM dan ratifikasi tersebut, Indonesia merupakan salah satu negara di dunia yang memiliki instrumen paling lengkap tentang HAM. Konsekuensinya, pemerintah berkewajiban untuk pelaksanaan instrumen dengan membuat kebijakan dan langkah-langkah untuk mengakui, menghormati, melindungi dan memenuhi hak asasi manusia. Sejalan dengan hal ini, pemerintah dan DPR wajib untuk mereformasi peraturan negara yang tidak sesuai dengan HAM. Di samping itu, penegakan HAM juga menjadi program pemerintah yang disebutkan dalam Rencana Pembangunan Jangka Panjang Nasional (RPJPN) 2005-2025. Sebagai acuan operasionalnya, pemerintah pun membuat Rencana Aksi Nasional Hak Asasi Manusia (RANHAM) tahun 2004-2009 melalui PP No. 40/2004 dan RANHAM tahun 2011-2014 melalui PP No. 23/2011.

Namun demikian, ratifikasi tersebut kemudian melahirkan perdebatan mengenai pelaksanaan perlindungan HAM, terutama tentang universalisme dan pertikularisme HAM. Kelompok liberal umumnya berpendapat, bahwa Indonesia harus melaksanakan semua ketentuan HAM yang terdapat dalam kovenan tersebut, tanpa disertai dengan penyesuaian-penyesuaian dengan konteks Indonesia, karena HAM itu bersifat universal. Sebagaimana diketahui, bahwa konsep universal HAM yang ada sekarang ini, termasuk yang terdapat dalam perjanjian-perjanjian tersebut berasal dari budaya dan peradaban Barat yang sekuler. Jadi, sangat dimungkinkan dan bahkan dibutuhkan untuk memahami dan menerapkan HAM dalam konteks masyarakat tertentu yang filosofi dan latar belakang budayanya tidak sama dengan latar belakang budaya Barat. Seperti kita ketahui, Indonesia yang berdasarkan Pancasila bukanlah negara sekuler dan bukan pula negara agama. Dalam hal lembaga-lembaga politik, Indonesia adalah sekuler, tetapi dalam hal filsafat negara, Indonesia bukanlah negara sekuler, karena ia mengakui keberadaan agama dalam kehidupan masyarakat dan negara.

Oleh karena itu, HAM pun didefiniskan dengan penyesuaian ini, sebagaimana disebutkan pada pasal 1 UU No. 39/1999 tersebut, yakni seperangkat hak yang melekat pada hakikat dan keberadaan manusia sebagai makhlukTuhan Yang Maha Esa dan merupakan anugerah-Nya yang wajib dihormati, dijunjung tinggi dan dilindungi oleh negara, hukum, Pemerintah, dan setiap orang demi kehormatan serta perlindungan harkat dan martabat manusia. UUD 1945 pun telah memberikan acuan tentang penyesaian HAM itu dengan memberikan pembatasan ekspresi HAM yang disebutkan secara eksplisit dalam pasal 28 (J) UUD 1945. Pembatasan ini dimaksudkan semata-mata untuk menjamin pengakuan dan penghormatan terhadap hak-hak dan kebebasan orang lain dan untuk memenuhi kebutuhan hanya dengan mengambil moralitas, nilai-nilai agama, keamanan dan ketertiban umum menjadi pertimbangan. Pembatasan ini juga dibenarkan oleh ICCRP, sebagaimana disebutkan dalam pasal 18: (3). Pembatasan ini merupakan "margin of appreciation" dalam pelaksanaan HAM, sebuah konsep yang dimunculkan oleh the European Court of 
Human Rights. ${ }^{24}$ Selain itu, pembatasan itu juga tidak bertentangan dengan demokrasi, karena demokrasi adalah keseimbangan antara kebebasan dan ketertiban berdasarkan aturan hukum (law and order). ${ }^{25}$

Di antara pembatasan yang sampai kini masih menimbulkan perdebatan adalah terkait dengan agama. Walaupun kebebasan beragama ini merupakan prinsip universal, pelaksanaan di Indonesia tidak bisa sepenuhnya sama dengan di negara-negara Barat yang sekuler. Bahkan di negara-negara Barat pun praktik kebebasan beragama ini tidak sama antara satu negara dengan negara lainnya. Kebebasan beragama ini terutama meliputi hak seseorang untuk menentukan agama, hak untuk beribadah, hak untuk memiliki tempat ibadah, hak untuk berpindah agama, hak untuk bebas dari diskriminasi dan hak untuk mendapatkan perlindungan dari penyiksaan. Di negara-negara sekuler kebebasan ini bahkan mencakup hak untuk tidak beragama, yang kemudian diklaim sebagai standar internasional. ${ }^{26}$

Yang juga menjadi partikularitas pelaksanaan HAM di Indonesia adalah adanya konsep kewajiban dasar manusia (KDM), yang dalam wacana internasional disebut human responsibility (tanggung jawab manusia). KDM, yang secara eksplisit disebutkan dalam UU HAM tersebut, diartikan sebagai “seperangkat kewajiban yang apabila hak dilaksanakan, tidak memungkinkan terlaksana dan tegaknya hak asasi manusia”. KAM ini antara lain disebutkan dalam pasal 69: (1), yakni "Setiap orang wajib menghormati hak asasi manusia orang lain, moral, etika, dan tata tertib kehidupan bermasyarakat, berbangsa, dan bernegara”. Sedangkan pasal 69: (2) disebutkan "Setiap hak asasi manusia seseorang menimbulkan kewajiban dasar dan tanggungjawab untuk menghormati hak asasi orang lain serta menjadi tugas Pemerintah untuk menghormati, melindungi, menegakkan, dan memajukannya". Bahkan KAM ini juga mencakup juga kewajiban terhadap pembatasan HAM sebagaimana disebutkan dalam pasal 70, yakni "Dalam menjalankan hak dan kebebasannya, setiap orang wajib tunduk kepada pembatasan yang ditetapkan Undang-undang dengan maksud untuk menjamin pengakuan serta penghormatan atas hak dan kebebasan orang lain dan untuk memenuhi tuntutan yang adil sesuai dengan pertimbangan moral, keamanan, dan ketertiban umum dalam suatu masyarakat demokratis".

\footnotetext{
${ }^{24}$ Lihat Abdul Hakim Garuda Nusantara, "Margin Apresiasi HAM", dalam Kompas, March 8, 2011.

${ }^{25}$ Penyesuaian tersebut juga didukung oleh negara-negara anggota Organisasi Konferensi Islam (OKI) dengan lahirnya Cairo Declaration of Human Rights in Islam pada tahun 1990, serta negara-negara anggota ASEAN dengan lahirnya ASEAN Human Rights Declaration pada tahun 2012 sebagaimana disebutkan di atas.

${ }^{26}$ Perlindungan dan penegakan HAM merupakan komitmen dan agenda bersama di era reformasi ini. Hal ini bisa dilihat dari amendemen terhadap UUD yang memasukkan HAM secara lebih rinci, dan legislasi UU No 39/1999 tentang Hak Asasi Manusia, dan ratifikasi sejumlah instrumen HAM PBB., antara lain International Covenant on Civil and Political Rights dengan UU No 12/2005. Salah satu dari HAM yang disebutkan dalam Universal Declaration of Human Rights 1948 (UDHR) dan UUD 1945 adalah kebebasan beragama, yaitu pasal 18 UDHR serta pasal 28 E (1) dan pasal 29 ayat (2) UUD 1945.
} 
Pemerintah di era reformasi (1998-sekarang) telah mengakui, menghormati dan melindungi HAM dan menjadikannya sebagai visi dari semua sektor pembangunan nasional. Berbeda dengan pemerintah Orde Baru yang sangat membatasi kebebasan, pemerintah di era reformasi sangat mendukung kebebasan sebagai unsur utama bagi penghormatan dan perlindungan HAM. Pemerintah menjamin kebebasan berekspresi, termasuk dalam bentuk kritik, oposisi, demonstrasi dan protes yang ditujukan kepada pemerintah dan lembaga-lembaga negara lainnya. Pemerintah juga menjamin kebebasan politik, termasuk pendirian partai agama yang dilarang di era Orde Baru. Yang lebih penting lagi adalah selama era ini pemerintah telah melakukan pemilihan umum yang bebas, di mana warga bisa menentukan pilihan mereka dengan bebas partai politik, calon anggota legislatif, presiden dan kepala daerah sesuai dengan aspirasi mereka sendiri.

Untuk memperkuat perlindungan HAM, UU tentang HAM tersebut mengamanatkan pembentukan Komisi Nasional Hak Asasi Manusia (Komnas HAM), yang sebenarnya sudah pernah didirikan pada tahun 1993 tetapi belum berfungsi secara efektif. Komisi ini memiliki tugas: (1) mengembangkan kondisi yang kondusif bagi pelaksanaan HAM sesuai dengan Pancasila, UUD 1945 dan Deklarasi Universal Hak Asasi Manusia, (2) untuk meningkatkan perlindungan dan penegakan HAM dalam rangka pengembangan kepribadian masyarakat Indonesia dan kemampuan mereka untuk berpartisipasi dalam berbagai bidang kehidupan. Komisi ini memiliki fungsi pengkajian, penelitian, penyuluhan, pemantau dan mediasi tentang HAM (pasal 76:1). Di samping itu, terdapat juga beberapa lembaga negara nonstruktural yang terkait dengan perlindungan HAM, terutama Komnas Perempuan, Komisi Perlindungan Anak Indonesia (KPAI), dan Ombudsman. Pemerintah juga mendorong peran civil society, terutama Lembaga Swadaya Masyarakat (LSM), dalam melakukan advokasi dalam bidang HAM, seperti Komisi Untuk Orang Hilang dan Tindakan Kekerasan (KONTRAS), Lembaga Studi dan Advokasi Masyarakat (ELSAM), dan sebagainya.

Kemajuan-kemajuan dalam penegakan HAM tersebut telah mendapatkan apresiasi dari berbagai pihak, termasuk Dewan HAM PBB (Human Rights Council of the United Nations) sebagaimana disebutkan dalam laporan Universal Periodic Review tahun 2012 lalu. Di antara langkah-langkah kongkrit yang dilakukan pemerintah adalah penyelenggaraan pendidikan atau pelatihan tentang HAM, termasuk bagi anggota militer dan polisi, ratifikasi instrumen HAM internasional, dukungan kepada aktivitas civil society, penghapusan impunitas (kekebalan hukuman), revisi hukum pidana, dan sebagainya. ${ }^{27}$

\section{Problem Penegakan HAM}

Namun di samping kemajuan-kemajuan tersebut, kini juga masih ada sejumlah

\footnotetext{
${ }^{27}$ Lihat National Report submitted in accordance with paragraph 5 of the annex to Human Rights Council resolution 16/21: Indonesia, presented by the Working Group on the Universal Periodic Review, Human Rights Council, Geneva, on 21 May-4 June, 2012.
} 
persoalan tentang HAM yang belum diselesaikan, baik yang merupakan warisan periode sebelumnya maupun yang muncul pada era reformasi ini. Di antara pelanggaran HAM masa lalu yang masih dituntut untuk diselesaikan adalah kasus Tanjung Priok pada 1984, penculikan aktivis pada 1997/1998, penembakan mahasiswa Trisakti, dan sebagainya. Pada era reformasi ini masih terdapat sejumlah masalah dan tantangan dalam praktik penegakan dan perlindungan HAM, baik yang bersifat substantif (materiil), struktural maupun kultural. ${ }^{28}$ Peraturan perundangan atau kebijakan pemerintah umumnya sudah tidak bertentangan dengan HAM, karena jika hal ini terjadi, ada upaya-upaya hukum untuk mengontrolnya, baik lembaga legislatif (DPR/DPRD), judicial review di Mahkamah Konstitusi (MK) atau Mahkamah Agung (MA) maupun melalui lembaga pengadilan biasa. Hanya saja, terdapat permasalahan terkait dengan konsep kebebasan dan batasan-batasannya, yang berakibat pada munculnya perbedaan tentang penilaian terhadap pelaksanaan HAM. Kelompok liberal berpendapat bahwa pembatasan dalam ekspresi kebebasan itu tidak dapat dibenarkan, tetapi UUD 1945 mengakui pembatasan ini, sebagaimana disebutkan dalam pasal 28 (J) UUD 1945 yang telah diuraikan di atas.

Pada masa Orde Baru memang perdebatan tentang pembatasan kebebasan ini terjadi di berbagai hal, baik terkait dengan politik, ekonomi maupun sosial budaya. Namun, di era reformasi ini, perdebatan serius tentang pembatasan kebebasan ini hanya yang berkaitan dengan kebebasan beragama, karena ajaran-ajaran agama itu sendiri juga menjadi pedoman umatnya yang berimplikasi kepada pembatasan untuk tidak melakukan hal-hal yang dilarang agama. Persoalan ekspresi kebebasan dan ekspresi hak untuk mempertahankan ajaran agama tersebut bisa menimbulkan ketegangan atau konflik di antara para pemeluk agama, baik internal maupun antarumat beragama. Oleh karena itu, muncul upaya-upaya pembatasannya melalui ketentuan perundangan (regulasi) untuk mewujudkan ketertiban serta menghindari munculnya ketegangan dan konflik dalam masyarakat yang disebabkan oleh ekspresi kebebasan yang berlebihan. Hanya saja, pembatasan kebebasan ini pun menimbulkan perdebatan, ada yang mendukungnya dan ada pula yang menolaknya. Sejumlah kelompok agama dan kelompok liberal tidak setuju terhadap regulasi pembatasan, dengan alasan bahwa regulasi itu hanya akan membatasi kebebasan beragama, yang sebenarnya merupakan hak yang tidak bisa dikurangi (non-derogable right). Namun demikian, negara dan kelompok mayoritas mendukung pembatasan itu melalui peraturan perundangan, dengan alasan bahwa kebebasan beragama secara individual (forum internum) memang merupakan hak yang tidak bisa dikurangi (non-derogable right), tetapi ekspresinya di ranah publik (forum externum) merupakan hak yang bisa dikurangi (derogable right) untuk melindungi moral, nilai-nilai agama, keamanan, dan ketertiban umum. UUD 1945 membenarkan adanya pembatasan ini, sebagaimana diatur dalam Pasal 28J ayat (2) UUD 1945 sebagaimana

\footnotetext{
${ }^{28} \mathrm{Hal}$ ini sesuai dengan teori yang dikemukakan Lawrence M. Friedman, bahwa penegakan hukum itu bergantung pada tiga hal, yakni substansi hukum, struktur hukum dan budaya hukum.
} 
disebutkan di atas. Pembatasan semacam ini juga dibenarkan oleh International Covenant on Civil and Political Rights, yang telah diratifikasi oleh DPR pada tahun 2005. ${ }^{29}$

Persoalan lainnya adalah kebebasan yang berimplikasi kepada penghinaan atau penodaan agama. Di Indonesia, yang berdasarkan Pancasila, tidak ada pemisahan sepenuhnya antara negara dan agama, dan bahwa tanggung jawab negara terhadap agama tidak hanya terbatas pada perlindungan kebebasan beragama, tetapi juga pelayanan kepada para pengikut agama, termasuk perlindungan hak warga negara untuk membela kemurnian ajaran dan praktik keagamaan mereka. Yang terakhir ini terjadi hanya jika ada penyimpangan mendasar dari prinsip-prinsip agama diperkenalkan oleh kelompok agama tertentu dan menyebabkan ketidakharmonisan sosial atau konflik, sebagaimana PNPS No. 1/1965 tentang Pencegahan Penyalahgunaan dan/atau Penodaan Agama. Pada masa Orde Baru PNPS tersebut diperkuat menjadiUU No.5/1969, sementara kertentuan hukumnya dimasukkan ke dalam KUHP, yakni pasal 156a.

Sejumlah kelompok agama dan aktivis LSM menilai PNPS tersebut sebagai peraturan perundangan yang tidak sejalan dengan HAM dan konstitusi negara; dan oleh karenanya, pada tahun 2008 mereka mengajukan judicial review terhadap PNPS No. 1/1965 tentang Pencegahan Penyalahgunaan dan/atau Penodaan Agama. Namun Mahkamah Konstitusi (MK) menolak usulan uji materiil itu melalui Putusannya No. 140/PUU-VII/2009, dengan alasan karena PNPS ini tidak membatasi kebebasan beragama, sebagaimana yang diargumentasikan pemohon. Sebaliknya, UU ini melarang mengeluarkan perasaan yang bersifat permusuhan, penodaan agama atau pokok-pokok ajaran agama yang ada di Indonesia. ${ }^{30}$ Hanya saja, karena PNPS No. 1/1965 itu ditetapkan di masa pemerintahan Orde Lama, yang notabene tidak demokratis, maka penerapannya harus selektif agar tetap sesuai dengan koridor sistem demokrasi.

Di samping itu, sejumlah inetelektual Muslim, tokoh liberal dan tokoh agama nonIslam menganggap Peraturan Daerah (Perda) bernuansa syari'ah di beberapa provinsi dan kabupaten/kota berpotensi pada perlakukan diskriminatif dan pelanggaran HAM, khususnya antara laki-laki dan perempuan serta antara Muslim dan non-Muslim. ${ }^{31}$ Berdasarkan alasan inilah, pada tahun 2007 tiga warga Tangerang, yaitu Lilis Maemudah, Tuti Rahmawati, dan Hesti Prabowo mengajukan uji materi (judicial review) Perda Kota Tangerang No. 8/ 2005 tentang Pelarangan Pelacuran ke Mahkamah Agung (MA). Namun MA menolak

${ }^{29}$ Dalam ICCPR pasal 18 ayat (3) disebutkan: "Kebebasan menjalankan dan menentukan agama atau kepercayaan seseorang hanya dapat dibatasi oleh ketentuan berdasarkan hukum, dan yang diperlukan untuk melindungi keamanan, ketertiban, kesehatan, atau moral masyarakat, atau hak-hak dan kebebasan mendasar orang lain".

${ }^{30}$ Lihat Putusan MK No. 140/PUU-VII/2009 tentang Permohonan Pengujian UndangUndang Nomor 1/PNPS/Tahun 1965 tentang Pencegahan Penyalahgunaan dan/atau Penodaan Agama, hlm. 275.

${ }^{31}$ Cf. Sukron Kamil dan Chaider S. Bamualim (ed.), Syariah Islam dan HAM, (Jakarta: CRSC UNI Jakarta dan Konrad Adenaur Stiftung, 2007), hlm. 218-220. 
permohonan ini, dan menyatakan bahwa Perda itu tidak melanggar peraturan yang lebih tinggi, HAM dan UUD 1945. Keputusan ini kemudian dijadikan sebagai preseden, bahwa Perda-Perda serupa di daerah-daerah lainnya pun tetap berlaku. Sebenarnya, sebelum pengundangan Perda-Perda sebenarnya telah dilakukan upaya-upaya sinkronisasi antara materi Perda itu dengan hukum nasional agar Perda itu tidak bertentangan dengan sistem hukum nasional dan HAM.

Adapun problem penegakan HAM yang bersifat struktural terkait dengan penegakan hukum baik oleh polisi, jaksa maupun hakim, yang secara umum masih belum cukup kuat dan kadang-kadang bahkan menimbulkan ekses yang melanggar HAM. Dalam beberapa kasus polisi ditengarai telah melanggar HAM, terutama dalam kasus yang berhubungan dengan demonstrasi yang dilakukan secara brutal atau dalam kaitan dengan tugas penanggulangan terorisme. Bahkan dalam sejumlah kasus, polisi hanya diam dan tidak mampu mencegah tindakan warga yang berpotensi melukai HAM, seperti dalam kasus konflik komunal atau agama. Hal ini terutama disebabkan oleh kurangnya kemampuan personil dan minimnya peralatan polisi untuk menangani demonstrasi yang dilakukan secara brutal. Di samping itu, hal ini juga disebabkan oleh sikap ketidakpastian (keraguraguan) pihak polisi sendiri jika tindakan yang sebenarnya dimaksudkan untuk pencegahan itu justru dituduh melanggar HAM. Di sisi lain, Komnas HAM tidak memiliki wewenang yang kuat dalam penegakan HAM, sehingga kedudukannya hanya mirip tim kajian, tim pencari fakta atau tim mediasi. Meski demikian, lembaga ini cukup kritis terhadap pelanggaran HAM yang terjadi, baik yang dilakukan oleh aparat negara maupun kelompok masyarakat. Apalagi jika kritik lembaga ini juga diperkuat oleh ormas-ormas besar dan LSM-LSM yang bergerak dalam penegakan HAM, seperti Komisi Untuk Orang Hilang dan Tindakan Kekerasan (KONTRAS), Lembaga Studi dan Advokasi Masyarakat (ELSAM), dan sebagainya.

Sedangkan tantangan dan problem yang bersifat kultural adalah adanya budaya hukum yang belum sepenuhnya kondusif bagi penegakan HAM. Tingkat kesadaran hukum warga Indonesia pada saat ini umumnya masih rendah yang tidak lepas dari tingkat pendidikan mereka yang rata-rata juga masih rendah. Munculnya sejumlah konflik komunal, baik yang berlatarbelakang ekonomi, politik maupun sosial menunjukkan hal ini. Demikian pula, munculmya sikap intoleransi beragama serta perselisihan dan konflik tentang pendirian rumah ibadah serta masih adanya kekerasan atas nama agama, walaupun jumlahnya sebenarnya sangat sedikit. Intoleransi itu sebenarnya merupakan ekses dari penggunaan kebebasan berekspresi yang terlalu bersemangat atau berlebihan, sehingga menimbulkan persoalan dalam masyarakat, seperti konflik atau perselisihan antarkelompok agama terutama karena persoalan pendirian rumah ibadah serta protes terhadap penodaan atau penistaan agama. Di antara kasus-kasus yang telah mendapatkan sorotan dari dunia internasional adalah kasus kekerasan terhadap Ahmadiyah serta protes terhadap izin pendirian rumah ibadah yang tidak sesuai dengan peraturan yang ada, yakni Peraturan Bersama (PBM) Menteri Agama dan Menteri dalam Negeri No. 9/2006 dan No. 8/2006, seperti kasus pendirian gereja GKI Yasmin Bogor. 
Sebenarnya kasus-kasus pendirian rumah ibadah ini tidak hanya terjadi di pulau Jawa yang beberapa kasus mengalami kesulitan mendirikan gereja, tetapi juga di Bali, Kupang, Manado, Manokwari dan sebagainya, dimana sebagian pendirian masjid juga mengalami kesulitan. ${ }^{32}$ Hanya saja, kasus-kasus di wilayah Timur ini tidak mendapatkan sorotan dari media nasional dan internasional. Intoleransi agama dan kasus-kasus kesulitan pendirian rumah ibadah bagi kelompok minoritas ini juga terjadi di negara-negara maju yang selama ini dinilai sudah menegakkan HAM. Hal ini terjadi seiring dengan proses globalisasi dan menguatnya politik identitas (identity politics) di negara-negara itu. Politik identitas ini kini tidak hanya diekspresikan sebagai perjuangan kelompok minoritas seperti ketika istilah ini dimunculkan pada awal 1970-an, tetapi juga diekspresikan oleh sebagian kelompok mainstream atau mayoritas untuk mempertahankan dominasi identitas mereka dalam kehidupan masyarakat.

Di samping itu, ada juga problem dan kecenderungan pemahaman keagamaan dan prilaku sebagian kecil kelompok agama yang bersifat eksklusif dan bahkan radikal, yang dipengaruhi oleh gerakan-gerakan Islam radikal di luar negeri. ${ }^{33}$ Di era reformasi, yang mendukung kebebasan dan demokrasi secara substantif ini, radikalisme telah muncul sebagai ekspresi kebebasan, baik yang berdasarkan agama, etnis, ekonomi atau motif lainnya. Mereka telah mengambil keuntungan dari iklim kebebasan yang ada untuk mengekspresikan dan menyebarkan ideologi mereka yang radikal dan ekstrem. Kelompok radikal dan ekstrem itu mengancam perlindungan dan penegakan HAM, karena banyak dari mereka berperilaku intoleran dan bahkan melakukan kekerasan dan teror terhadap kelompok lain yang dianggap sebagai musuh. Sebagaimana diatur dalam pasal 28A UUD 1945, bahwa setiap orang berhak untuk hidup serta berhak mempertahankan hidup dan kehidupannya.

Pemerintah dan DPR telah melakukan upaya-upaya serius untuk membatasi dan memerangi radikalisme dan terorisme bermotif agama melalui pendekatan keamanan dan pendekatan budaya. Pada tahun 2003 DPR telah menetapkan UU No. 15/2003 tentang Pemberantasan Tindak Pidana Terorisme. Kemudian pada tahun 2010, pemerintah membentuk Badan Nasional Penanggulangan Terorisme (BNPT) untuk memperkuat upaya-upaya memerangi terorisme. Badan ini pun melibatkan tokoh agama dan ulama dalam pelaksanaan program-programnya, terutama dalam bentuk deradikalisasi dan kontra-radikalisme.

\footnotetext{
${ }^{32}$ Walaupun telah terjadi sejumlah kasus perselisihan tentang pendirian rumah ibadah, dalam kenyataannya jumlah rumah ibadah untuk kelompok minoritas merupakan terbesar di dunia. Data Badan Pusat Statistik (BPS) tahun 2010 menunjukkan sebagai berikut: jumlah pemeluk Islam adalah 207.176 .162 orang (87,18 \%) dengan jumlah masjid 255.147 (76,42 \%) atau 1:812, jumlah pemeluk Kristen Protestan adalah 16.528 .513 (6,96 \%) dengan jumlah gereja $50.565(15,15 \%)$ atau 1:327, sedangkan jumlah pemeluk Katolik adalah $6.907 .873(2,91 \%)$ dengan jumlah gereja 11.191 (3,35 \%) atau 1:617.

${ }^{33}$ Radikalisme agama disebabkan oleh beberapa faktor, baik faktor eksternal (internasional) terutama ketidakadilan dunia dan persoalan konflik Palestina-Israel dan Perang Afganistan maupun faktor internal, terutama pemahaman keagamaan yang eksklusif dan literal serta kondisi suatu negara yang dinilai kurang menunjukkan keadilan dan kesejahteraan rakyat.
} 
Sejak sekitar 10 tahun terakhir, para tokoh dan organisasi keagamaan, terutama Nahdlatul Ulama dan Muhammadiyah, juga telah melakukan upaya-upaya untuk mencegah dan membatasi radikalisme agama. Mereka mensosialisasikan pemahaman yang benar tentang ajaran agama (khususnya Islam), dengan mempromosikan perdamaian dan harmoni sesuai dengan misi Islam itu sendiri sebagai rahmat bagi alam semesta (rahmat li al-'âlamîn). Mereka juga menjelaskan bahwa perjuangan untuk aspirasi atau protes terhadap setiap penyimpangan harus dilakukan secara legal dan konstitusional serta melalui cara-cara yang bijak (hikmah), bukan melalui cara-cara kekerasan dan teror, apalagi jika kekerasan dan teror yang dilakukan atas nama jihad. Mereka juga mengutuk kekerasan dan teror itu dan menganggapnya sebagai tindakan yang menodai Islam dan melanggar HAM. Kampanye tentang Islam rahmat li al-‘̂alamîn juga ditujukan kepada pihak non-Muslim, untuk menghindari kesalahpahaman tentang Islam, terutama setelah serangan WTC pada tahun 2001.

\section{Penutup}

Uraian di atas menunjukkan, bahwa sejak awal Islam telah mengakui eksistensi hak asasi manusia (HAM), karena Allah telah menjadikan manusia sebagai khalifah di atas bumi ini dan menganugerahinya dengan martabat yang tinggi di atas mahluk-mahluk lain. Islam pun memerintahkan kepada umatnya untuk menghormati dan melindungi harkat dan martabat manusia itu. Para ulama kemudian merumuskannya dengan konsep maqâshid al-syarî’ah (tujuan syari'ah), yakni untuk mewujudkan kemaslahatan manusia yang meliputi keniscayaan (dharûriyyât) dan kebutuhan (hâjiyyât) manusia yang eksistensinya harus diwujudkan dan dilindungi. Hanya saja, pelaksanaan HAM itu tidak bisa terlepas dari agama dan budaya suatu masyarakat tertentu, sehingga dalam beberapa kasus pelaksanaan HAM bersifat partikular dalam rangka penyesuaian ini dan bukan untuk mempertahankan kekuasaan suatu pemerintahan tertentu.

Meski demikian, pada saat ini masih banyak negara-negara Muslim yang belum sepenuhnya menegakkan dan melindungi HAM. Sebagai salah satu negara Muslim, seluruh komponen bangsa Indonesia di era reformasi ini telah berkomitmen untuk melakukan upaya-upaya perlindungan dan penegakan HAM sejalan dengan penerapan sistem demokrasi secara substantif, baik dalam bentuk amandemen konstitusi, legislasi tentang HAM, ratifikasi perjanjian-perjanjian internasional maupun perumusan rencana aksi HAM (RANHAM). Hanya saja, pada saat ini masih ada sejumlah masalah atau kendala dalam perlindungan HAM itu yang disebabkan oleh beberapa faktor, baik yang bersifat substantif, struktural maupun kultural. Oleh karena itu, diperlukan upaya-upaya untuk mengatasi persoalan, kendala dan tantangan itu, baik oleh pemerintah, DPR, civil society maupun organisasiorganisasi keagamaan, terutama melalui peningkatan kapasitas para penegak hukum serta pendidikan kewarganegaraan yang menekankan pendidikan HAM. 
MIQOT Vol. XXXVIII No. 2 Juli-Desember 2014

\section{Pustaka Acuan}

'Imarah, Muhammad. Al-Islâm wa Huqûq al-Insân: Darûrât lâ Huqûq. Damaskus: Dar alSalam, 2004.

al-Farra', Abû Ya'lâ. Al-Ahkâm al-Sulthâniyyah. Mesir: Mustafâ al-Bâbî al-Halabî.

al-Ghazali, Muhammad. Huqûq al-Insân: Ta'âlim al-Islâm wa I'lân al-Umam al-Muttahidah. Iskandaria: Dar al-Da'wah, 1993.

al-Jauziyyah, Ibn Qayyim. I'lâm al-Muwaqqi'în. Beirut: Dar al-Kutub al-"ilmiyyah, 1991.

An-Naim, Abdullah Ahmad. Nahw Tathwîr al-Tasyrî‘ al-Islâmî. Kairo: Sina li Al-Nasyr, 1994.

Barry, Norman P. An Introduction to Modern Political Theory. New York: St. Martin's Press, 1981.

Becker, Werner. Die Fretheit, die wer Weinem. Munchen-Zurich: R. Riper \& Co., Verlag, 1982.

Budiardjo, Miriam. "Hak-hak Asasi Manusia dalam Dimensi Global" dalam Jurnal Ilmu Politik, Vol. 10, 1990.

Esposito, John L., dan James P. Piscatori, "Democratization and Islam", dalam Middle East Journal, Vol. 45, No. 3, 1991.

Khallâf, 'Abd al-Wahhâb. 'Ilm Ushûl Fiqh. Kuwait : Dâr al-Qalam, cet. 12, 1978.

Maarif, Ahmad Syafii. Islam dan Masalah Kenegaraan. Jakarta: LP3ES, 2003.

Mawdudi, Abul A'la. Human Rights in Islam. Leicester: The Islamic Foundation, 1976.

Nusantara, Abdul Hakim Garuda. "Margin Apresiasi HAM", dalam Kompas, March 8, 2011.

Pollis, Adamantia. "Human Rights", dalam Mary Hawkesworth dan Maurice Kogan (ed.), Encyclopedia of Government and Politics, Vol. 2. London dan New York: Routledge, 1992.

Rahman, Fazlur. "Non-Muslim Minority on an Islamic State", dalam Journal Institute of Muslim Minority Affairs, Vol. 7 No. 1, 1986.

Sâbiq, Al-Sayyid. Fiqh Al-Sunnah, Jilid II. Beirut : Dâr al-Kitâb al-AArabî, 1987.

Sjadzali, Munawir. Islam dan Tata Negara: Ajaran, Sejarah dan Pemikiran, (Jakarta : UIPress, 1990.

Syaltut, Mahmud. Al-Islâm 'Aqîdah wa Syarî’ah. Kairo: Dar al-Qalam, 1966.

Yamin, Muhammad (ed.), Naskah Persiapan Undang-Undang Dasar 1945, Jilid I. Jakarta: Prapanca, 1959. 